\title{
Relative Salt Tolerance of Seven Japanese Spirea Cultivars
}

Yuxiang Wang ${ }^{1,5}$, Liqin $\mathrm{Li}^{2,5}$, Youping Sun ${ }^{3,6}$, and Xin Dai ${ }^{4}$

ADDITIONAL INDEX WORDs. photosynthesis, reclaimed water, Spiraea japonica, visual quality

Summary. Spirea (Spiraea sp.) plants are commonly used in landscapes in Utah and the intermountain western United States. The relative salt tolerance of seven japanese spirea (Spiraea japonica) cultivars (Galen, Minspi, NCSX1, NCSX2, SMNSJMFP, Tracy, and Yan) were evaluated in a greenhouse. Plants were irrigated with a nutrient solution with an electrical conductivity (EC) of $1.2 \mathrm{dS} \cdot \mathrm{m}^{-1}$ (control) or saline solutions with an EC of 3.0 or $6.0 \mathrm{dS} \cdot \mathrm{m}^{-1}$ once per week for 8 weeks. At 8 weeks after the initiation of treatment, all japanese spirea cultivars irrigated with saline solution with an EC of $3.0 \mathrm{dS} \cdot \mathrm{m}^{-1}$ still exhibited good or excellent visual quality, with all plants having visual scores of 4 or $5(0=$ dead, $1=$ severe foliar salt damage, 2 = moderate foliar salt damage, 3 = slight foliar salt damage, $4=$ minimal foliar salt damage, 5 = excellent), except for Tracy and Yan, with only $29 \%$ and $64 \%$, respectively, of plants with visual scores less than 3 . When irrigated with saline solution with an EC of $6.0 \mathrm{dS} \cdot \mathrm{m}^{-1}$, both 'Tracy' and 'Yan' plants died, and $75 \%$ of 'NCSX2' plants died. 'Minspi' showed severe foliar salt damage, with $32 \%$ of plants having a visual score of $1 ; 25 \%$ of plants died. 'Galen' and 'NCSX1' had slight-tomoderate foliar salt damage, with $25 \%$ and $21 \%$, respectively, of plants with visual scores of 2 or less. However, 64\% of 'SMNSJMFP' plants had good or excellent visual quality, with visual scores more than 4 . Saline irrigation water with an EC of $3.0 \mathrm{dS} \cdot \mathrm{m}^{-1}$ decreased the shoot dry weight of 'Galen', 'Minspi', 'SMNSJMFP', and 'Yan' by 27\%, 22\%, 28\%, and 35\%, respectively, compared with that of the control. All japanese spirea cultivars had 35\% to 56\% lower shoot dry weight than the control when they were irrigated with saline irrigation water with an EC of $6.0 \mathrm{dS} \cdot \mathrm{m}^{-1}$. The japanese spirea were moderately sensitive to the salinity levels in this experiment. 'Galen' and 'SMNSJMFP' japanese spirea exhibited less foliar salt damage and reductions in shoot dry weight and were relatively more tolerant to the increased salinity levels tested in this study than the remaining five cultivars (Minspi, NCSXI, NCSX2, Tracy, and Yan).

S alinity is a serious environmental problem worldwide, especially in arid and semi-arid regions. It is estimated that $\approx 800$ million ha of arable lands are currently affected by salinity stress (Food and Agriculture Organization of the United Nations, 2008). The chemical compositions in water and salt-affected soils vary with sources and locations. Sodium chloride $(\mathrm{NaCl})$, sodium sulfate $\left(\mathrm{Na}_{2}\right.$. $\left.\mathrm{SO}_{4}\right)$, calcium chloride $\left(\mathrm{CaCl}_{2}\right)$, calcium sulfate $\left(\mathrm{CaSO}_{4}\right)$, magnesium chloride $\left(\mathrm{MgCl}_{2}\right)$, magnesium sulfate $\left(\mathrm{MgSO}_{4}\right)$, potassium chloride $(\mathrm{KCl})$, and sodium carbonate $\left(\mathrm{Na}_{2} \mathrm{CO}_{3}\right)$ all contribute to salinity stress; however, $\mathrm{NaCl}$ is the most prevalent salt (Taiz and Zeiger, 2015). Dissolved salts in the root zone can cause low water potential, thereby limiting the water available to plants. Furthermore, high concentrations of ions that accumulate in plant tissue, particularly sodium $\left(\mathrm{Na}^{+}\right)$and chloride $\left(\mathrm{Cl}^{-}\right)$, can cause specific ion effects on plant growth and development, nutrient uptake and imbalance, and plant photosynthesis (Grattan and Grieve, 1999; Taiz and Zeiger, 2015).

Aesthetically appealing landscapes are needed to meet the demand of rapidly growing urban populations for high-quality living environments. Landscape irrigation will consume large quantities of fresh water that are already low in many regions. Alternative waters such as brackish groundwater and treated and reclaimed sewage effluent (reclaimed water) can provide additional water for landscape use (Tanji et al., 2008). These alternative waters are saline with varying chemical compositions and typically contain $\mathrm{l}$ to $7 \mathrm{~g} \cdot \mathrm{L}^{-1}$ total dissolved salts (TDS) (Glenna et al., 2009). If there is no opportunity to drain the accumulated salts, then they can quickly build and injure salt-sensitive species. Practices like improving drainage, maintaining a leaching fraction, monitoring salt concentrations in reclaimed water, and using salt-tolerant plant species are needed to reduce salinity stress (Niu and Cabrera, 2010).

Japanese spirea is an ideal landscape plant for border, foundation, and mass plantings. It has a dense, compact habit with large clusters of pink or white flowers that bloom in late spring and summer. It is an ornamental plant for gardeners in Utah and the intermountain western United States that offers a wide range of sizes and cultivars. 'Galen' japanese spirea has rich pink flowers, purple-red new growth in spring, and blue-green foliage in summer (Morton Arboretum, 2018). 'Minspi' japanese spirea is a low-growing shrub with splashy green, yellow, and cream variegated leaves and bright pink flowers (Proven Winners, 2018a). 'NCSXI' japanese spirea was introduced by Proven Winners (Monrovia, 2018a). It is an exceptional low-growing shrub with purple flowers and bright candy apple red foliage that emerges in spring and then matures to a bold yellow foliage. 'NCSX2' japanese spirea is a shrub with green foliage and red flowers (Proven Winners, 2018b). 'SMNSJMFP' japanese spirea has pink flowers and green foliage (Spring Meadow Nursery, 2018). 'Tracy' japanese spirea is a patented cultivar

\begin{tabular}{llll}
\hline $\begin{array}{l}\text { Units } \\
\text { To convert U.S. to SI, } \\
\text { multiply by }\end{array}$ & U.S. unit & SI unit & $\begin{array}{l}\text { To convert SI to U.S., } \\
\text { multiply by }\end{array}$ \\
\hline 0.4047 & $\mathrm{acre}(\mathrm{s})$ & $\mathrm{ha}$ & 2.4711 \\
29.5735 & $\mathrm{fl} \mathrm{oz}$ & $\mathrm{mL}$ & 0.0338 \\
0.3048 & $\mathrm{ft}$ & $\mathrm{m}$ & 3.2808 \\
0.0929 & $\mathrm{ft}^{2}$ & $\mathrm{~m}^{2}$ & 10.7639 \\
0.0283 & $\mathrm{ft}^{3}$ & $\mathrm{~m}^{3}$ & 35.3147 \\
3.7854 & $\mathrm{gal}$ & $\mathrm{L}$ & 0.2642 \\
2.54 & inch(es) & $\mathrm{cm}^{3}$ & 0.3937 \\
6.4516 & inch & $\mathrm{cm}$ & 0.1550 \\
1 & mmho/cm & $\mathrm{dS} \cdot \mathrm{m}^{-1}$ & 1 \\
28.3495 & $\mathrm{oz}$ & $\mathrm{g}$ & 0.0353 \\
7.4892 & $\mathrm{oz} / \mathrm{gal}$ & $\mathrm{g} \cdot \mathrm{L}^{-1}$ & 0.1335 \\
1 & $\mathrm{ppm}$ & $\mathrm{mg} \cdot \mathrm{L}^{-1}$ & 1 \\
$\left({ }^{\circ} \mathrm{F}-32\right) \div 1.8$ & ${ }^{\circ} \mathrm{F}$ & ${ }^{\circ} \mathrm{C}$ & $\left({ }^{\circ} \mathrm{C} \times 1.8\right)+32$ \\
& & & \\
\hline
\end{tabular}


discovered by Timothy Wood from an open pollination of 'Wilma' fritsch spirea (Spiraea fritschiana) as the female parent and japanese spirea as the male parent (Monrovia, 2018b). It produces massive pink flowers and orange foliage in spring, deep yellow in the summer, and golden orange in autumn. 'Yan' japanese spirea has pink flowers and vibrant gold foliage (Morton Arboretum, 2018).

Research-based information regarding spirea salt tolerance is limited. The salt tolerance of japanese spirea has been reported in extension articles. For example, japanese spirea and bumalda japanese spirea (Spiraea $\times$ bumalda) are listed as shrubs

Received for publication 22 Jan. 2019. Accepted for publication 20 Feb. 2019.

Published online 2 April 2019.

This research was supported in part by the U.S. Department of Agriculture (USDA) National Institute of Food and Agriculture Hatch project UTA01381, New Faculty Start-Up Funds from the Office of Research and Graduate Studies, and the Center for Water-Efficient Landscaping at Utah State University. This research was also supported by the Utah Agricultural Experiment Station, Utah State University, and approved as journal paper no. 9160 . We are grateful for the in-kind support of plant materials from Spring Meadow Nursery (Grand Haven, MI) and valuable comments from anonymous reviewers. We appreciate the financial support from Grassology Peak Discipline Foundation of Xinjiang Uygur Autonomous Region, National Modern Agricultural Technology \& Industry System (CARS-34) of China, and The Group Matching Project for Study Abroad from Xinjiang Uygur Autonomous Region to Yuxiang Wang, and from National Natural Science Foundation of China (\#31600255) and The Matching Funds from Huzhou Central Hospital to Liqin Li as visiting scholars at Utah State University (Logan, UT).

The content is solely the responsibility of the authors and does not necessarily represent the official views of the funding agencies. Mention of a trademark, proprietary product, or vendor does not constitute a guarantee or warranty of the product by the USDA and the American Society for Horticultural Science, and it does not imply its approval to the exclusion of other products or vendors that also may be suitable.

${ }^{1}$ Western Arid Region Grassland Resources and Ecology Key Lab, Xinjiang Agricultural University, No. 311 East Nongda Road, Urumqi, Xinjiang 830052, China

${ }^{2}$ Huzhou Central Hospital, Huzhou Hospital affiliated with Zhejiang University, 198 Hongqi Road, Huzhou, Zhejiang 31300, China

${ }^{3}$ Department of Plants, Soils and Climate, Utah State University, 4820 Old Main Hill, Logan, UT 84322

${ }^{4}$ Utah Agricultural Experiment Station, Utah State University, 4810 Old Main Hill, Logan, UT 84322

${ }^{5}$ These authors contributed equally.

${ }^{6}$ Corresponding author. E-mail: youping.sun@usu. edu.

This is an open access article distributed under the CC BY-NC-ND license (https://creativecommons.org/ licenses/by-nc-nd/4.0/).

https://doi.org/10.21273/HORTTECH04280-19 tolerant to saline soils and salt spray (Appleton et al., 2015). Bumalda japanese spirea is sensitive to salt spray (Beckerman and Lerner, 2009), whereas japanese spirea has moderate tolerance to salt spray (Jull, 2009). However, these inconsistent reports are based on anecdotal observations without defined thresholds for salt tolerance categories. Therefore, it is necessary to perform additional research to investigate their salt tolerance and to select salt-tolerant japanese spirea for landscape use. In this study, seven spirea cultivars were irrigated with saline water to mimic reclaimed water irrigation. Plant morphological and physiological responses to salt stress were evaluated to determine differences in salt tolerance among cultivars.

\section{Materials and methods}

Plant materials and growing CONDITIONS. On 2 Mar. 2018, rooted cuttings in 32 -cell trays $(5.5 \times 5.5 \times$ $10.0 \mathrm{~cm}$ ) of 7 japanese spirea cultivars [Galen (Double Play ${ }^{\circledR}$ Artisan $^{\circledR}$ USPP2 1,712), Minspi (Double Play ${ }^{\circledR}$ Painted Lady ${ }^{\mathrm{T} M}$ ), NCSXl (Double Play $^{\circledR}$ Candy Corn $^{\mathrm{TM}}$ USPP28,313), NCSX2 (Double Play Doozie ${ }^{\mathrm{TM}}$ USPPAF), SMNSJMFP (Double Play ${ }^{\circledR}$ Pink USPP26,995), Tracy (Double Play ${ }^{\circledR}$ Big Bang ${ }^{\text {TM }}$ USPP21,588), and Yan (Double Play ${ }^{\circledR}$ Gold USPP21,615)] were received from Spring Meadow Nursery (Grand Haven, MI). They were grown in a greenhouse in Logan, UT (lat. $41^{\circ} 45^{\prime} 28^{\prime \prime} \mathrm{N}$; long. $111^{\circ} 48^{\prime} 47^{\prime \prime} \mathrm{W}$; elevation $1409 \mathrm{~m}$ ), and watered with tap water [electrical conductivity $(\mathrm{EC})=$ $\left.0.36 \mathrm{dS} \cdot \mathrm{m}^{-1} ; \mathrm{pH}=7.95\right]$. The sodium adsorption ratio (SAR) of the tap water was 0.04 , and the major ions in the tap water were calcium $\left(\mathrm{Ca}^{2+}\right)$, magnesium $\left(\mathrm{Mg}^{2+}\right)$, sulfate $\left(\mathrm{SO}_{4}{ }^{2-}\right), \mathrm{Cl}^{-}, \mathrm{Na}^{+}$, and potassium $\left(\mathrm{K}^{+}\right)$at $47.2,17.3,8.9,3.4$, 1.4 , and $0.4 \mathrm{mg} \cdot \mathrm{L}^{-1}$, respectively. Three weeks later, plants $(\approx 10$ inches tall) were potted in 1-gallon, injection-molded, polypropylene containers (PClD4; Nursery Supplies, Orange, CA) filled with a soilless growing substrate consisting of $75 \%$ peat moss (Canadian sphagnum peat moss; Sun Gro Horticulture, Agawam, MA), 25\% vermiculite (Therm-O-Rock West, Chandler, AZ), and $24.3 \mathrm{~g} / \mathrm{ft}^{3}$ white athletic field marking gypsum ( $92 \%$ calcium sulfate dihydrate, $21 \%$ calcium, $17 \%$ sulfur; Western Mining and Minerals, Bakersfield, CA). All plants were irrigated with tap water until treatments started. The average air temperature in the greenhouse was $26.2 \pm$ $1.9^{\circ} \mathrm{C}$ during the day and $19.6 \pm$ $5.0^{\circ} \mathrm{C}$ at night. The average daily light integral inside the greenhouse was $17.5 \pm$ $3.6 \mathrm{~mol} \cdot \mathrm{m}^{-2} \cdot \mathrm{d}^{-1}$ during the experiment. From 1 Mar. to 2 May, supplemental lights were provided from 0600 to 2200 HR using 1000-W high-pressure sodium lamps (Hydrofarm, Petaluma, CA) at light intensities of $223 \pm 37 \mu \mathrm{mol} \cdot \mathrm{m}^{-2} \cdot \mathrm{s}^{-1}$ at canopy level when the light intensity inside the greenhouse was less than $544 \mu \mathrm{mol} \cdot \mathrm{m}^{-2} \cdot \mathrm{s}^{-1}$.

Treatments. A nutrient solution with an EC of $1.2 \mathrm{dS} \cdot \mathrm{m}^{-1}$ was prepared by adding $0.8 \mathrm{~g} \cdot \mathrm{L}^{-1} 15 \mathrm{~N}-$ 2.2P-12.5K water-soluble fertilizer (Peters Excel 15-5-15 Ca-Mag Special; ICL Specialty Fertilizers, Dublin, $\mathrm{OH})$ to tap water and used as the control. Saline solution with an EC of $3.0 \mathrm{dS} \cdot \mathrm{m}^{-1}$ was prepared by adding $0.46 \mathrm{~g} \cdot \mathrm{L}^{-1} \mathrm{NaCl}$ and $0.44 \mathrm{~g} \cdot \mathrm{L}^{-1} \mathrm{cal}-$ cium chloride $\left(\mathrm{CaCl}_{2}\right)$ to the aforementioned nutrient solution, and saline solution with an EC of $6.0 \mathrm{dS} \cdot \mathrm{m}^{-1}$ was prepared by adding $1.25 \mathrm{~g} \cdot \mathrm{L}^{-1} \mathrm{NaCl}$ and $1.20 \mathrm{~g} \cdot \mathrm{L}^{-1} \mathrm{CaCl}_{2}$ to the nutrient solution. This mixture was used because $\mathrm{NaCl}$ is the common salt found in reclaimed water (Niu and Cabrera, 2010), and $\mathrm{CaCl}_{2}$ is used to forestall potential calcium deficiencies (Carter and Grieve, 2006). The $\mathrm{pH}$ of all solutions was adjusted to $6.5 \pm 0.1$ using nitric acid. Both nutrient and saline solutions were prepared in 100L tanks; EC was confirmed using an EC meter (LAQUA Twin; Horiba, Kyoto, Japan) before irrigation.

Four weeks after transplanting (27 Apr. 2018), uniform plants were chosen for the experiment and all plants were pruned $(\approx 15 \mathrm{~cm}$ tall). From 2 May to 14 June 2018, treatment solutions were applied once per week for 8 weeks. At each irrigation, plants were irrigated with $1 \mathrm{~L}$ of treatment solution per plant, resulting in a leaching fraction of $\approx 24 \%$. Between treatment solution irrigations, plants were irrigated with 300 $\mathrm{mL}$ of nutrient solution whenever the substrate surface became dry. Irrigation frequency varied with environmental conditions and treatment solution. Plants with higher salinity need less irrigation because of lower water use resulting from the reduced transpiration and leaf area. On 25 June, all plants were harvested. All plants were sprayed with tebuconazole 


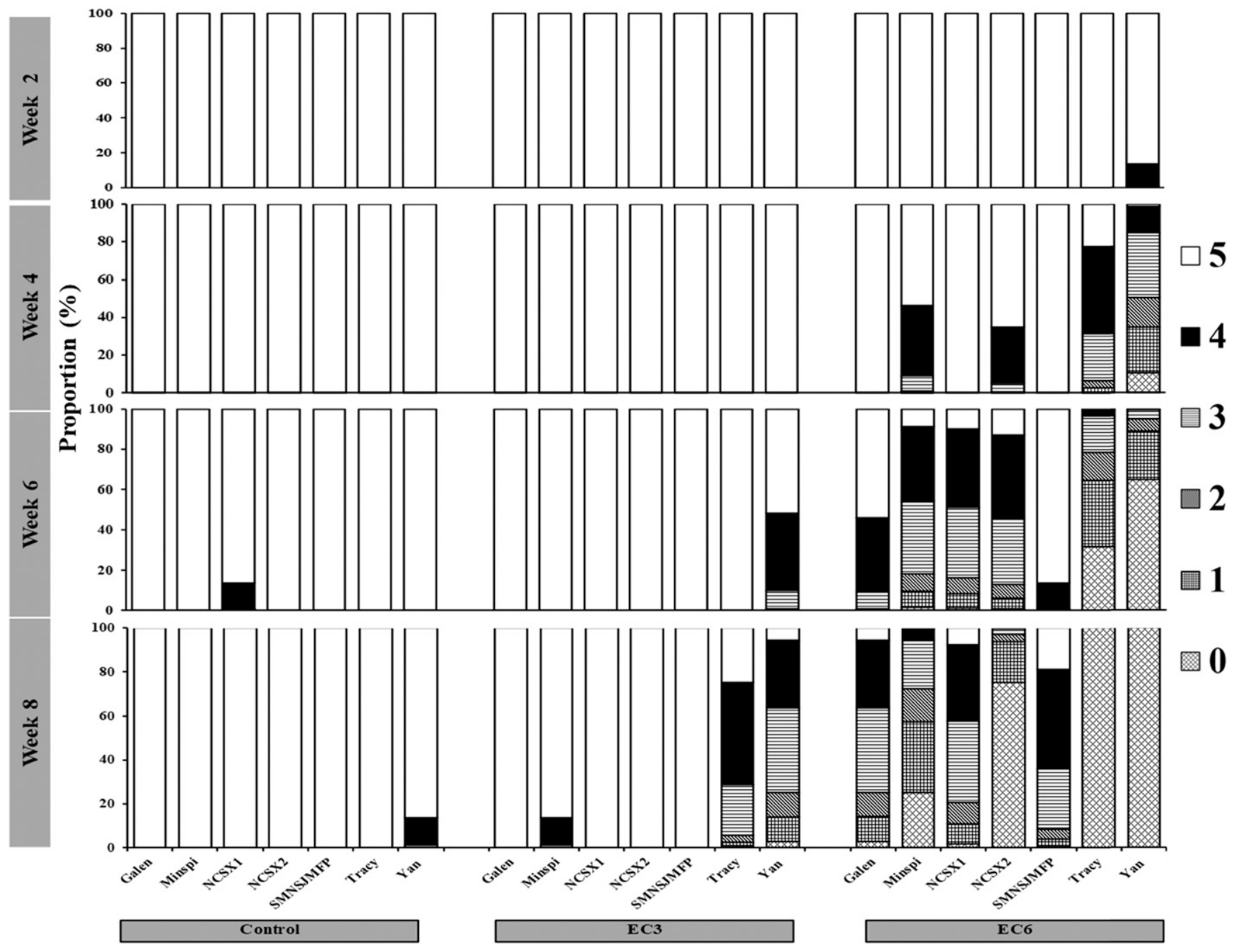

Fig. 1. Visual score of seven japanese spirea cultivars irrigated with a nutrient solution with an electrical conductivity (EC) of $1.2 \mathrm{dS} \cdot \mathrm{m}^{-1}$ (control) or a saline solution with an EC of $3.0 \mathrm{dS} \cdot \mathrm{m}^{-1}(\mathrm{EC} 3)$ or $6.0 \mathrm{dS} \cdot \mathrm{m}^{-1}$ (EC6) in a greenhouse. Saline solution was created by adding sodium chloride $(\mathrm{NaCl})$ and calcium chloride $\left(\mathrm{CaCl}_{2}\right)$ to the nutrient solution. Plants were harvested after the eighth irrigation $(8$ weeks after initiating treatment). $0=$ dead; $1=$ severe $($ more than $90 \%)$ foliar salt damage (salt damage: leaf burn and necrosis); $2=$ moderate $(50 \%$ to $90 \%)$ foliar salt damage; $3=$ slight (less than $50 \%)$ foliar salt damage; 4 = good quality with minimal foliar salt damage; and 5 = excellent without foliar salt damage (Sun et al., 2015 ). $1 \mathrm{dS} \cdot \mathrm{m}^{-1}=1 \mathrm{mmho} / \mathrm{cm}$.

(Bayer Advanced, Research Triangle Park, NC) to control powdery mildew (Podosphaera xanthii) as needed.

LEACHATE EC. The pour-through method described by Cavins et al. (2008) and Wright (1986) was used to determine leachate EC. In brief, a saucer was placed under the container that was drained for $30 \mathrm{~min}$ after treatment solution was applied. Then, a total of $100 \mathrm{~mL}$ of distilled water was poured on the surface of the substrate to obtain leachate in the saucer. Leachate solution was tested using an EC meter. One plant per treatment per cultivar was chosen for measurement. Leachate EC readings were averaged across cultivars.
Plant growth and visual QUALITY. Height (centimeter) from the pot rim to the top of the plant and two perpendicular widths (centimeter) were recorded 1 week before harvest. The number of inflorescences was also recorded. At harvest, foliar salt damage was rated by giving a visual score based on a reference scale from 0 to 5: 0 = dead; 1 = severe (more than 90\%) foliar damage (salt damage: leaf burn and necrosis); 2 = moderate $(50 \%$ to $90 \%)$ foliar salt damage; $3=$ slight (less than $50 \%$ ) foliar salt damage; $4=$ good quality with minimal foliar damage; and $5=$ excellent without foliar salt damage (Sun et al., 2015). The foliar salt damage rating did not consider plant size. At harvest, plant shoots were cut at the substrate surface. Leaf area (square centimeter) was determined using an area meter (LI-3100; LI-COR Biosciences, Lincoln, NE). Plant shoots were dried in an oven at $70^{\circ} \mathrm{C}$ for $3 \mathrm{~d}$, and shoot dry weight (grams) was determined.

LEAF RELATIVE CHLOROPHYLL CONTENT. Relative chlorophyll content [soil-plant analysis development (SPAD) reading] was measured using a hand-held chlorophyll meter (SPAD502 Plus; Minolta Camera Co., Osaka, Japan) 1 week before harvest. The third, fourth, or fifth healthy and fully expanded leaves, counting from the top of the plant downward, were chosen 


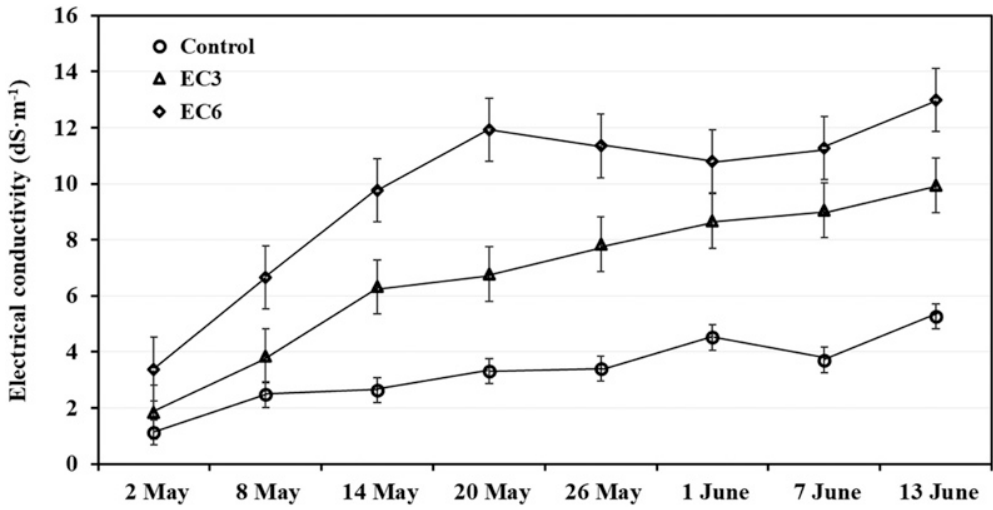

Fig. 2. Leachate electrical conductivity (EC) during the experimental period. Control denotes nutrient solution with an EC of $1.2 \mathrm{dS} \cdot \mathrm{m}^{-1}$, whereas EC3 and EC6 denote saline solutions with an EC of $3.0 \mathrm{dS} \cdot \mathrm{m}^{-1}$ and $6.0 \mathrm{dS} \cdot \mathrm{m}^{-1}$, respectively. Saline solution was created by adding sodium chloride $(\mathrm{NaCl})$ and calcium chloride $\left(\mathrm{CaCl}_{2}\right)$ to the nutrient solution. Leachate $\mathrm{EC}$ readings were averaged across seven japanese spirea cultivars. Error bars represent the SD of seven measurements. $1 \mathrm{dS} \cdot \mathrm{m}^{-1}=1 \mathrm{mmho} / \mathrm{cm}$.
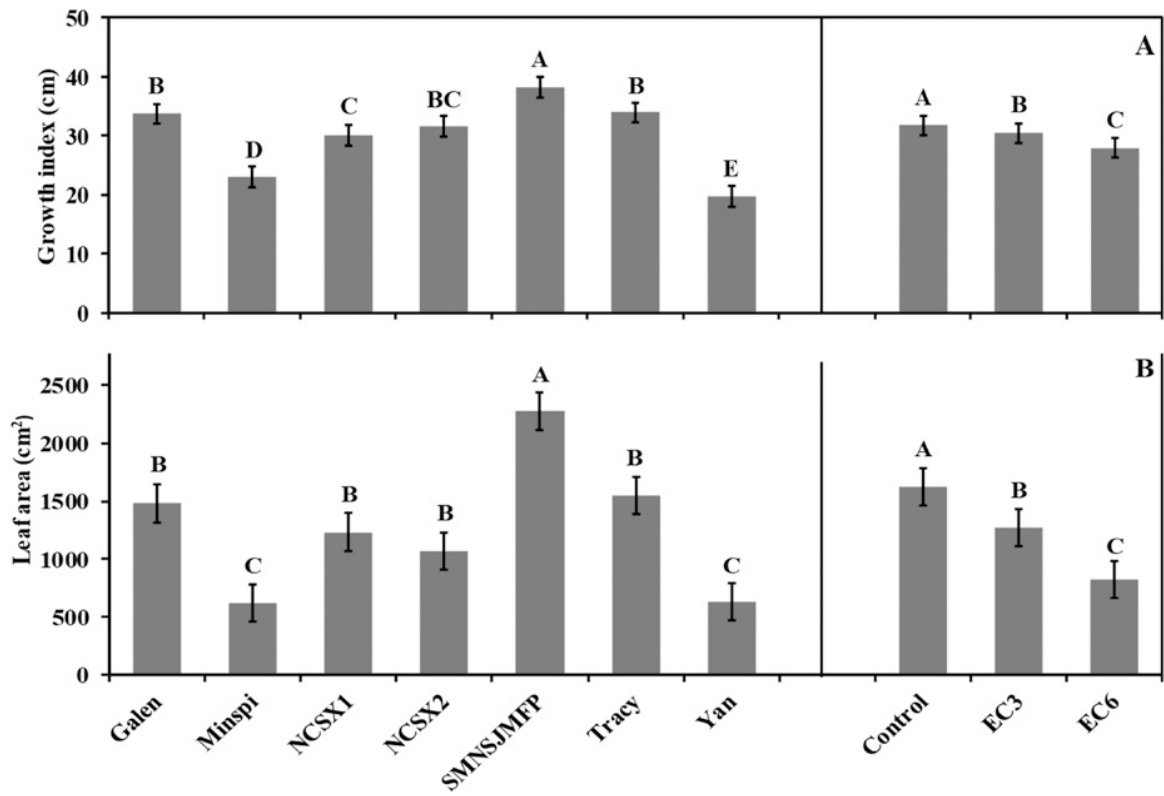

Fig. 3. The growth index [(height + width $1+$ width 2$) / 3](A)$ and leaf area (B) of seven japanese spirea cultivars irrigated with a nutrient solution with an electrical conductivity (EC) of $1.2 \mathrm{dS} \cdot \mathrm{m}^{-1}$ (control) or a saline solution with an EC of $3.0 \mathrm{dS} \cdot \mathrm{m}^{-1}(\mathrm{EC} 3)$ or $6.0 \mathrm{dS} \cdot \mathrm{m}^{-1}(\mathrm{EC} 6)$ in a greenhouse. Saline solution was created by adding sodium chloride $(\mathrm{NaCl})$ and calcium chloride $\left(\mathrm{CaCl}_{2}\right)$ to the nutrient solution. Same uppercase letters above the error bars are not significantly different among cultivars or treatments with Tukey's multiple comparison $(\alpha=$ $0.05) .1 \mathrm{dS} \cdot \mathrm{m}^{-1}=1 \mathrm{mmho} / \mathrm{cm} ; 1 \mathrm{~cm}=0.3937$ inch; $1 \mathrm{~cm}^{2}=0.1550$ inch $^{2}$.

for measurements. Five leaves were measured on each plant and the average number was recorded.

GaS EXCHANGE. Leaf net photosynthetic rate $\left(\mathrm{P}_{\mathrm{n}}\right)$, stomatal conductance (gs), transpiration (E), and water use efficiency (WUE) of four plants per treatment per cultivar were measured on 19 and 20 June using a portable photosynthesis system with an automatic universal PLC6 broad leaf cuvette (CIRAS-3; PP Systems, Amesbury, MA). The third, fourth, and fifth healthy and fully expanded leaves, counting from the top of the plant downward, were chosen for measurement. Environmental conditions within the cuvette were maintained at a photosynthetic photon flux of $1000 \mu \mathrm{mol} \cdot \mathrm{m}^{-2} \cdot \mathrm{s}^{-1}$ and carbon dioxide concentration of $400 \mu \mathrm{mol} \cdot \mathrm{mol}^{-1}$. Data were recorded when the environmental conditions and gas exchange rates in the cuvette stabilized. These measurements were performed on sunny days between 1000 and $1400 \mathrm{HR}$, and plants were watered well the day before to avoid drought stress.

EXPERIMENTAL DESIGN AND STATISTICAL ANALYSIS. The experiment used a completely randomized design with seven plants per treatment per cultivar. Two-way analysis of variance was performed for all plant growth parameters except visual score, which was analyzed using repeated measures for multinomial data. In addition, the number of inflorescences was analyzed as negative binomial data. The mean separation among treatments and cultivars was adjusted using Tukey's method for multiplicity with $\alpha=0.05$. All statistical analyses were performed using the GENMOD and GLIMMIX procedures of SAS/STAT 14.3 in SAS (version 9.4; SAS Institute, Cary, NC).

\section{Results and discussion}

Visual Quality. All japanese spirea plants had excellent visual quality at 2 weeks after initiating treatments (Fig. 1). At 4 weeks, all plants irrigated with saline solution with an EC of $3.0 \mathrm{dS} \cdot \mathrm{m}^{-1}$ still had excellent visual quality. However, at 4 weeks, foliar salt damage became apparent on japanese spirea plants when irrigated with saline solution with an EC of $6.0 \mathrm{dS} \cdot \mathrm{m}^{-1}$. 'Yan' displayed moderate foliar salt damage, with $65 \%$ of plants having visual scores more than 2; 'Tracy' exhibited slight foliar salt damage, with $93 \%$ of plants having visual scores of 3 or more, and 'Minspi' and 'NCSX2' had minimal foliar salt damage, with $91 \%$ and $95 \%$, respectively, of plants rated greater than 4 . All 'Galen', 'NCSXI', and 'SMNSJMFP' japanese spirea irrigated with saline solution with an EC of $6.0 \mathrm{dS} \cdot \mathrm{m}^{-1}$ had visual scores of 5 .

At 6 weeks, all japanese spirea plants irrigated with saline solution with an EC of $3.0 \mathrm{dS} \cdot \mathrm{m}^{-1}$ showed good or excellent visual quality except 'Yan'. 'Yan' exhibited minimal foliar salt damage, with $90 \%$ of plants rated 4 or 5 (Fig. 1). With an EC of 6.0 $\mathrm{dS} \cdot \mathrm{m}^{-1}, 32 \%$ and $65 \%$ of 'Tracy' and 'Yan' plants died, respectively, and $33 \%$ and $24 \%$ of plants exhibited 
Table 1. Number of inflorescences and shoot dry weight of seven japanese spirea cultivars irrigated with a nutrient solution with an electrical conductivity (EC) of $1.2 \mathrm{dS} \cdot \mathrm{m}^{-1}$ (control) or a saline solution with an EC of $3.0 \mathrm{dS} \cdot \mathrm{m}^{-1}(\mathrm{EC} 3)$ or 6.0 $\mathrm{dS} \cdot \mathrm{m}^{-1}$ (EC6) in a greenhouse. Saline solution was created by adding sodium chloride $(\mathrm{NaCl})$ and calcium chloride $\left(\mathrm{CaCl}_{2}\right)$ to the nutrient solution. Plants were harvested after the eighth irrigation $(8$ weeks after initiating treatment $){ }^{\mathrm{z}}$

\begin{tabular}{|c|c|c|c|c|c|c|}
\hline \multirow[b]{2}{*}{ Cultivar } & \multicolumn{3}{|c|}{ Inflorescences (no.) } & \multicolumn{3}{|c|}{ Shoot dry wt $(\mathrm{g})^{\mathrm{z}}$} \\
\hline & Control & EC3 & EC6 & Control & EC3 & EC6 \\
\hline Galen & $44 \mathrm{a}^{\mathrm{y}}$ & $29 \mathrm{~b}$ & $27 \mathrm{~b}$ & $32.8 \mathrm{aA}^{\mathrm{x}}$ & $23.8 \mathrm{bA}$ & $17.0 \mathrm{cAB}$ \\
\hline Minspi & $14 \mathrm{a}$ & $15 \mathrm{a}$ & $7 \mathrm{~b}$ & $13.5 \mathrm{aD}$ & $10.6 \mathrm{bD}$ & $6.0 \mathrm{cD}$ \\
\hline NCSXI & $-^{\mathrm{w}}$ & - & - & $16.2 \mathrm{aCD}$ & $14.7 \mathrm{aCD}$ & $10.6 \mathrm{bBC}$ \\
\hline NCSX2 & $-^{\mathrm{w}}$ & - & - & $21.3 \mathrm{aB}$ & $20.9 \mathrm{aAB}$ & $12.0 \mathrm{bBC}$ \\
\hline SMNSJMFP & $35 \mathrm{a}$ & $23 \mathrm{~b}$ & $21 \mathrm{~b}$ & $37.0 \mathrm{aA}$ & $26.8 \mathrm{bA}$ & $19.4 \mathrm{cA}$ \\
\hline Tracy & - $^{\mathrm{w}}$ & - & - & $21.1 \mathrm{aBC}$ & $17.2 \mathrm{aBC}$ & $10.5 \mathrm{bBCD}$ \\
\hline Yan & $25 \mathrm{a}$ & $23 \mathrm{a}$ & $一^{\mathrm{v}}$ & $16.5 \mathrm{aBCD}$ & $10.8 \mathrm{bCD}$ & 9.5 bCD \\
\hline
\end{tabular}

${ }^{\mathrm{z}} \mathrm{l} \mathrm{dS} \cdot \mathrm{m}^{-1}=1 \mathrm{mmho} / \mathrm{cm} ; \mathrm{l} \mathrm{g}=0.0353 \mathrm{oz}$.

${ }^{y}$ Means with the same lowercase letters within a row and dependent variable are not significantly different among treatments with Tukey's multiple comparison $(\alpha=0.05)$.

${ }^{\mathrm{x}}$ Means with the same uppercase letters within a column are not significantly different among cultivars with Tukey's multiple comparison $(\alpha=0.05)$.

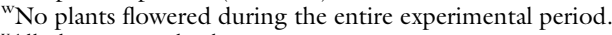

${ }^{\mathrm{v}}$ All plants were dead.

Table 2. The relative chlorophyll content (SPAD) and photosynthetic rate $\left(P_{n}\right)$ of seven japanese spirea cultivars irrigated with a nutrient solution with an electrical conductivity (EC) of $1.2 \mathrm{dS} \cdot \mathrm{m}^{-1}$ (control) or a saline solution with an EC of $3.0 \mathrm{dS} \cdot \mathrm{m}^{-1}(\mathrm{EC3})$ or $6.0 \mathrm{dS} \cdot \mathrm{m}^{-1}$ (EC6) in a greenhouse. Saline solution was created by adding sodium chloride $(\mathrm{NaCl})$ and calcium chloride $\left(\mathrm{CaCl}_{2}\right)$ to the nutrient solution. ${ }^{\mathrm{z}}$

\begin{tabular}{|c|c|c|c|c|c|c|}
\hline \multirow[b]{2}{*}{ Cultivar } & \multicolumn{3}{|c|}{ SPAD } & \multicolumn{3}{|c|}{$P_{n}\left(\mu \mathrm{mol} \cdot \mathrm{m}^{-2} \cdot \mathrm{s}^{-1}\right)^{\mathrm{z}}$} \\
\hline & Control & EC3 & EC6 & Control & EC3 & EC6 \\
\hline Galen & $44.4 \mathrm{a}^{\mathrm{y}} \mathrm{A}^{\mathrm{x}}$ & $45.0 \mathrm{aA}$ & $45.6 \mathrm{aA}$ & $15.1 \mathrm{aA}$ & $11.1 \mathrm{bA}$ & $8.9 \mathrm{bA}$ \\
\hline Minspi & $34.6 \mathrm{aB}$ & $29.7 \mathrm{bC}$ & $28.9 \mathrm{bB}$ & $4.8 \mathrm{aC}$ & $4.9 \mathrm{aC}$ & $2.1 \mathrm{bC}$ \\
\hline NCSXl & $11.6 \mathrm{aD}$ & $11.1 \mathrm{aD}$ & $12.8 \mathrm{aC}$ & $10.0 \mathrm{aB}$ & $7.4 \mathrm{bB}$ & $5.3 \mathrm{cA}$ \\
\hline NCSX2 & $38.1 \mathrm{aB}$ & $34.0 \mathrm{bBC}$ & - & $10.8 \mathrm{aB}$ & $8.6 \mathrm{bAB}$ & $5.2 \mathrm{bBC}$ \\
\hline SMNSJMFP & $37.3 \mathrm{aB}$ & $34.4 \mathrm{abB}$ & $31.7 \mathrm{bB}$ & $13.3 \mathrm{aAB}$ & $12.0 \mathrm{aA}$ & $7.5 \mathrm{bA}$ \\
\hline Tracy & $34.9 \mathrm{aB}$ & $35.3 \mathrm{aB}$ & — $^{\mathrm{w}}$ & $10.5 \mathrm{aB}$ & $6.6 \mathrm{bBC}$ & - \\
\hline Yan & $17.0 \mathrm{aC}$ & $12.3 \mathrm{bD}$ & - & $3.7 \mathrm{aC}$ & $1.6 \mathrm{bD}$ & - \\
\hline
\end{tabular}

${ }^{\mathrm{z}} 1 \mathrm{dS} \cdot \mathrm{m}^{-1}=1 \mathrm{mmho} / \mathrm{cm} ; 1 \mathrm{~m}^{2}=10.7639 \mathrm{ft}^{2}$.

${ }^{y}$ Means with the same lowercase letters within a row and dependent variable are not significantly different among treatments by Tukey's multiple comparison or between treatments with Student's $t$ test $(\alpha=0.05)$.

${ }^{x}$ Means with the same uppercase letters within a column are not significantly different among cultivars by Tukey's multiple comparison with $(\alpha=0.05)$.

wPlants died or had severe foliar salt damage.

severe foliar salt damage, with a visual score of 1 . 'Minspi' showed moderate foliar salt damage, with $91 \%$ of plants with visual scores more than 2 . 'NCSX1' and 'NCSX2' had slight foliar salt damage, with more than $84 \%$ of plants with visual scores of 3 or more. 'Galen' and 'SMNSJMFP' still had excellent visual quality, with $91 \%$ and $99 \%$, respectively, of plants with ratings of 4 or 5 . Visual quality of 'Galen' and 'SMNSJMFP' was significantly better than that of 'Tracy', 'Yan', 'Minspi', 'NCSXl', and 'NCSX2' $(P<0.05)$.

At 8 weeks, the impact of saline irrigation water on plant aesthetic quality became remarkably worse (Fig. 1). When irrigated with saline
Although 'Galen' had better visual appearance than 'NCSXl' at 6 weeks after initiating treatment, they did not differ at 8 weeks after treatment was initiated $(P=0.51)$. Approximately $36 \%$ of 'Galen' plants had good or excellent visual quality. SMNSJMFP appeared to be the most salt-tolerant cultivar in terms of visual quality. The mortality rate of this cultivar was consistently less than $1 \%$, whereas $64 \%$ of plants had good or excellent visual quality with ratings of 4 or 5 . In addition, 'SMNSJMFP' plants irrigated with saline solution with an EC $6.0 \mathrm{dS} \cdot \mathrm{m}^{-1}$ outperformed other cultivars $(P<0.05)$.

It appeared that 'Tracy' and 'Yan' japanese spirea were sensitive to saline irrigation water applied in the study, whereas 'SMNSJMFP' and 'Galen' japanese spirea were relatively salt-tolerant. High salinity is known to cause plant injuries such as leaf necrosis, burn, and premature discoloration, which lead to poor visual quality and poor marketability of ornamental plants (Chen et al., 2017; Sun et al., 2018). In this study, the substrate EC values gradually increased with the irrigation of saline solution (Fig. 2). The average leachate EC of plants irrigated with nutrient solution increased from 1.13 to $5.27 \mathrm{dS} \cdot \mathrm{m}^{-1}$, whereas irrigation with saline solution with EC values of 3.0 and $6.0 \mathrm{dS} \cdot \mathrm{m}^{-1}$ resulted in the average leachate $\mathrm{EC}$ values increasing from 1.85 to $9.94 \mathrm{dS} \cdot \mathrm{m}^{-1}$ and from 3.39 to $12.98 \mathrm{dS} \cdot \mathrm{m}^{-1}$, respectively. The EC values of the leachate collected from the nutrient solution irrigation were consistently lower than those of the leachate from saline solution irrigations after the second irrigation. This is why foliar salt damage changed over time and differed among saline water irrigations.

GROWTH INDEX AND LEAF AREA. Saline water irrigation affected plant growth of japanese spirea, as indicated by the growth index and leaf area, and all cultivars responded similarly (Fig. 3). Compared with the control, the average growth index values of all japanese spirea cultivars irrigated with saline solution with EC values of 3.0 and $6.0 \mathrm{dS} \cdot \mathrm{m}^{-1}$ decreased by $4 \%$ and $12 \%$, respectively. The average leaf area of all japanese spirea cultivars irrigated with saline solution with EC values of 3.0 and $6.0 \mathrm{dS} \cdot \mathrm{m}^{-1}$ decreased by $21 \%$ and 

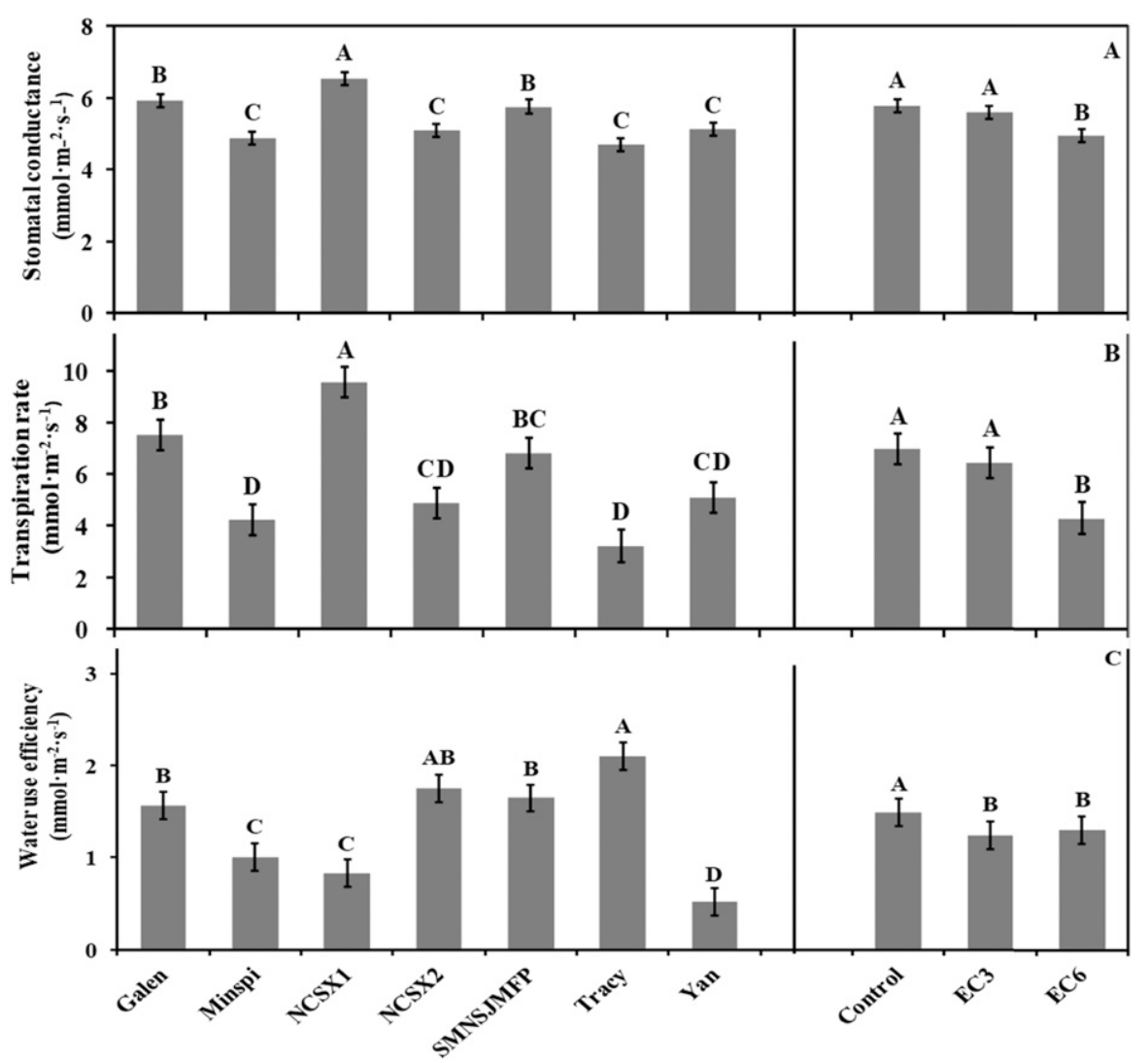

Fig. 4. The stomatal conductance (A), transpiration rate (B), and water use efficiency $(C)$ of seven japanese spirea cultivars irrigated with a nutrient solution with an electrical conductivity (EC) of $1.2 \mathrm{dS} \cdot \mathrm{m}^{-1}$ (control) or a saline solution with an EC of $3.0 \mathrm{dS} \cdot \mathrm{m}^{-1}$ (EC3) or $6.0 \mathrm{dS} \cdot \mathrm{m}^{-1}$ (EC6) in a greenhouse. Saline solution was created by adding sodium chloride $(\mathrm{NaCl})$ and calcium chloride $\left(\mathrm{CaCl}_{2}\right)$ to the nutrient solution. Same uppercase letters above the error bars are not significantly different among cultivars or treatments with Tukey's multiple comparison $(\alpha=0.05) .1 \mathrm{dS} \cdot \mathrm{m}^{-1}=1 \mathrm{mmho} / \mathrm{cm} ; 1 \mathrm{~m}^{2}=10.7639 \mathrm{ft}^{2}$.

$49 \%$, respectively. Similarly, stunted growth and reduction in leaf area have been observed in many ornamental plants irrigated with saline water (Chen et al., 2017; Liu et al., 2017; Sun et al., 2018). This might be caused by a salt-induced water deficit because salinity lowers the water potential of soil solution, thus making water less available to plants. Turgordependent activities such as stem elongation and leaf expansion are the most sensitive to water deficits (Taiz and Zeiger, 2015). Additionally, as an adaptation to a saline environment, the salt-induced water deficit stimulates leaf abscission that could significantly reduce transpiration and water loss. 'SMNSJMFP' japanese spirea had the greatest growth index and leaf area, whereas 'Yan' had the smallest growth index and leaf area (Fig. 3). This is because all japanese spirea cultivars tested in irrigated with saline solution with an $\mathrm{EC}$ of $6.0 \mathrm{dS} \cdot \mathrm{m}^{-1}$, the inflorescences of 'Galen', 'Minspi', and 'SMNSJMFP' were reduced by $39 \%, 50 \%$, and $40 \%$, respectively. Compared with the control, the shoot dry weight of 'Galen', 'Minspi', 'SMNSJMFP', and 'Yan' irrigated with saline solution with an EC of $3.0 \mathrm{dS} \cdot \mathrm{m}^{-1}$ decreased by $27 \%$, $22 \%, 28 \%$, and $35 \%$, respectively ( $\mathrm{Ta}-$ ble 1). The shoot dry weights of 'NCSX1', 'NCSX2', and 'Tracy' plants irrigated with saline solution with an EC of $3.0 \mathrm{dS} \cdot \mathrm{m}^{-1}$ were similar to that of the control. All japanese spirea cultivars irrigated with saline solution with an EC of $6.0 \mathrm{dS} \cdot \mathrm{m}^{-1}$ had $35 \%$ to $56 \%$ lower shoot dry weights than the control. Increased salinity reduced shoot dry weight in a variety of plant species (Chen et al., 2017; Liu et al., 2017; Sun et al., $2015,2018)$. The reduced shoot growth of japanese spirea plants observed in this study should have resulted from the salts accumulated in plant root zone, as indicated by the EC values of the leachate solution collected immediately after irrigation (Fig. 2). Due to plant growth habits, SMNSJMFP' and 'Galen' japanese spirea had the greatest shoot dry weight, whereas 'Minspi' had the lowest shoot dry weight (Table 1 ).

\section{RELATIVE CHLOROPHYLL} CONTENT (SPAD) AND GAS EXCHANGE. Increased salinity did not affect the SPAD readings of 'Galen', 'NCSXl', and 'Tracy' (Table 2). Saline solution with an EC of $3.0 \mathrm{dS} \cdot \mathrm{m}^{-1}$ decreased the SPAD readings of 'NCSX2', 'Minspi', and 'Yan' by $11 \%, 14 \%$, and $27 \%$, respectively, compared with that of the control. The SPAD readings of 'Minspi' and 'SMNSJMFP' decreased by $16 \%$ and $15 \%$, respectively, when they were irrigated with saline solution with an EC of $6.0 \mathrm{dS} \cdot \mathrm{m}^{-1}$. Compared with the control, the $\mathrm{P}_{\mathrm{n}}$ of 'Galen', 'NCSXl', 'NCSX2', and 'Tracy' irrigated with saline solution with an EC of 3.0 $\mathrm{dS} \cdot \mathrm{m}^{-1}$ decreased by $20 \%$ to $37 \%$; however, that of 'Yan' decreased by $57 \%$ (Table 2). Saline solution with an EC of $6.0 \mathrm{dS} \cdot \mathrm{m}^{-1}$ further reduced the $P_{n}$ of 'Galen', 'NCSXI', and 'NCSX 2 ' by $41 \%, 47 \%$, and $52 \%$, respectively. The $P_{n}$ of 'Minspi' and 'SMNSJMFP' irrigated with saline solution with an EC of $3.0 \mathrm{dS} \cdot \mathrm{m}^{-1}$ were similar to that of the control, but saline solution with an EC of 6.0 
$\mathrm{dS} \cdot \mathrm{m}^{-1}$ decreased the $\mathrm{P}_{\mathrm{n}}$ of 'Minspi' and 'SMNSJMFP' by $56 \%$ and $44 \%$, respectively. The negative impact of salinity on plant photosynthesis has been reported previously (Liu et al., 2017; Sun et al., 2015). High concentrations of $\mathrm{Na}^{+}$and/or $\mathrm{Cl}^{-}$in chloroplasts might lead to the decrease in photosynthesis (Taiz and Zeiger, 2015).

The $g_{S}$, transpiration rate, and water use efficiency of japanese spirea were impacted by saline water irrigation, and all cultivars showed similar responses (Fig. 4). The gs and transpiration rate of japanese spirea plants irrigated with saline solution with an EC of $3.0 \mathrm{dS} \cdot \mathrm{m}^{-1}$ was similar to that of the control. However, the water use efficiency of japanese spirea irrigated with saline solution with an EC of 3.0 $\mathrm{dS} \cdot \mathrm{m}^{-1}$ decreased by $17 \%$ compared with the control. Saline irrigation water with an EC of $6.0 \mathrm{dS} \cdot \mathrm{m}^{-1}$ further reduced the $g_{S}$, transpiration rate, and water use efficiency of japanese spirea by $14 \%, 38 \%$, and $13 \%$, respectively. These results are in line with previous reports that indicated that increased salinity negatively impacts plant $g_{S}$ and transpiration rates (Liu et al., 2017; Sun et al., 2015).

\section{Conclusions}

Seven japanese spirea cultivars were evaluated for salinity tolerance using irrigation water spiked with $\mathrm{NaCl}$ and $\mathrm{CaCl}_{2}$ that could be expected from reclaimed water. Japanese spirea was moderately sensitive to the salinity levels in this greenhouse experiment. 'Galen' and 'SMNSJMFP' japanese spirea were relatively more salt-tolerant than the other five cultivars (Minspi, NCSX1, NCSX2, Tracy, and Yan), with lower mortality, less foliar salt damage, and less growth reduction with increased salinity. These results are valuable for growers and landscape professionals because they can aid in plant selection for regions where saline water and low-quality irrigation water are used. It might also be helpful for spirea breeders when breeding salttolerant japanese spirea cultivars for landscape use.

\section{Literature cited}

Appleton, B., V. Greene, A. Smith, S. French, B. Kane, L. Fox, A. Downing, T. Gilland, and D. Close. 2015. Trees and shrubs that tolerate saline soils and salt spray drift. Virginia Tech/Virginia State Univ. Coop. Ext. Publ. 430-031.

Beckerman, J. and B.R. Lerner. 2009. Salt damage in landscape plants. Purdue Univ. Coop. Ext. ID-412-W.

Carter, C.T. and C.M. Grieve. 2006. Salt tolerance of floriculture crops, p. 279287. In: M.A. Khan and D.J. Weber (eds.). Ecophysiology of high salinity tolerant plants. Springer Science + Business Media, Dordrecht, The Netherlands.

Cavins, T.J., B.E. Whipker, and W.C. Fonteno. 2008. Pourthru: A method for monitoring nutrition in the greenhouse. Acta Hort. 779:289-297.

Chen, L., Y. Sun, G. Niu, Q. Liu, and J. Altland. 2017. Relative salt tolerance of eight japanese barberry cultivars. HortScience 52:1810-1815.

Food and Agriculture Organization of the United Nations. 2008. FAO Soils Portal Management of some problem soils: Saltaffected soils. I Nov. 2018. <http://www. fao.org/soils-portal/soil-management/ management-of-some-problem-soils /saltaffected-soils /more-information-on-saltaffected-soils/en/>.

Glenna, E.P., M. Casey, G. Vanda, L.N Pamela, J. Fiona, and A. Janick. 2009. Deficit irrigation of a landscape halophyte for reuse of saline waste water in a desert city. Landsc. Urban Plan. 89:57-64.

Grattan, S.R. and C.M. Grieve. 1999. Salinity-mineral nutrient relations in horticultural crops. Scientia Hort. 78:127-157.

Jull, L.G. 2009. Winter salt injury and salt-tolerant landscape plants. Univ. Wisconsin Coop. Ext. A3877.

Liu, Q., Y. Sun, G. Niu, J. Altland, L. Chen, and L. Jiang. 2017. Morphological and physiological responses of ten ornamental taxa to saline water irrigation. HortScience 52:1816-1822.

Monrovia. 2018a. Double Play ${ }^{\circledR}$ Candy Corn ${ }^{\mathrm{TM}}$ spirea: Spiraea japonica 'NCSXl'. Plant Patent \#28,313. 7 Nov. 2018. <https://www.monrovia.com/plantcatalog/plants $/ 6210 /$ double-playcandy-corn-spirea/>.
Monrovia. 2018b. Double Play® Big Bang $^{\mathrm{TM}}$ spirea: Spiraea japonica 'Tracy'. Plant Patent \#21,588. 7 Nov. 2018. <https://www.monrovia.com/plantcatalog/plants/3040/double-play-bigbang-spirea $/>$.

Morton Arboretum. 2018. Japanese spirea. 7 Nov. 2018 . <http://www. mortonarb.org/trees-plants/tree-plantdescriptions/japanese-spirea>.

Niu, G. and R.I. Cabrera. 2010. Growth and physiological responses of landscape plants to saline water irrigation - A review. HortScience 45:1605-1609.

Proven Winners. 2018a. Double Play ${ }^{\circledR}$ Painted Lady ${ }^{\circledR}$ spirea. 7 Nov. 2018. <https://www.provenwinners.com/ plants/spiraea/double-play-paintedlady-spirea-spiraea-japonica>.

Proven Winners. 2018b. Double Play® Doozie ${ }^{\circledR}$ spirea. 7 Nov. 2018. <https:// www.provenwinners.com / plants / spiraea/double-play-doozie-spireaspiraea- $x>$.

Spring Meadow Nursery. 2018. Double Play® Pink spirea: Spiraea japonica 'SMNSJMFP'. USPP 26,995; CBR 5632. 7 Nov. 2018 . <https:// s pring meadownursery.com / plantfinder/double-play-pink-74130>.

Sun, Y., G. Niu, and C. Perez. 2015. Relative salt tolerance of seven Texas Superstar ${ }^{\circledR}$ perennials. HortScience 50:1562-1566.

Sun, Y., G. Niu, C. Perez, H.B. Pemberton, and J. Altland. 2018. Responses of marigold cultivars to saline water irrigation. HortTechnology 28:166-171.

Taiz, L. and E. Zeiger. 2015. Plant physiology and development. 6th ed. Sinauer Assoc., Sunderland, MA.

Tanji, K., S. Grattan, C. Grieve, A. Harivandi, L. Rollins, D. Shaw, B. Sheikh, and L. Wu. 2008. A comprehensive literature review on salt management guide for landscape irrigation with recycled water in coastal southern California. I June 2018. <www.salinitymanagement.org>.

Wright, R.D. 1986. The pour-through nutrient extraction procedure. HortScience 21:227-229. 